Mediatization: Theorizing the Interplay Between Media, Culture, and Society

Hepp, Andreas; Hjarvard, Stig; Lundby, Knut

Published in:

Media, Culture \& Society

DOI:

$10.1177 / 0163443715573835$

Publication date:

2015

Document version

Early version, also known as pre-print

Citation for published version (APA):

Hepp, A., Hjarvard, S., \& Lundby, K. (2015). Mediatization: Theorizing the Interplay Between Media, Culture, and Society. Media, Culture \& Society, 37(2), 314-324. https://doi.org/10.1177/0163443715573835 


\title{
Mediatization: Theorizing the Interplay between Media, Culture and Society
}

Andreas Hepp, University of Bremen

Stig Hjarvard, University of Copenhagen

Knut Lundby, University of Oslo

Published in Media, Culture \& Society, February 18, 2015, pp. 1-11, DOI: 10.1177/0163443715573835. The published article is available as Online First:

http://mcs.sagepub.com/content/early/2015/02/16/0163443715573835.full

\begin{abstract}
In response to Deacon and Stanyer's article 'Mediatization: Key Concept or Conceptual Bandwagon?', we argue that they build their criticism on a simplified methodology. They mistake a media-centered approach for a media-centric one, and they do not capture how mediatization research engages with the complex relationship between changes in media and communication on the one hand and changes in various fields of culture and society on the other. We conclude that the emergence of the concept of mediatization is part of a paradigmatic shift within media and communication research.
\end{abstract}

\section{Keywords}

Causality, conceptual design, cross-disciplinary, history, mediatization, social change

\section{Corresponding author}

Stig Hjarvard, Department of Media, Cognition and Communication, University of Copenhagen, Denmark. Email: stig@hum.ku.dk 


\section{Introduction}

During the last decade 'mediatization' has emerged as an important concept and theoretical framework for considering the interplay between media, culture and society - a problematic which must be at the very heart of concerns among the present journal's readers. The authors of this article have all contributed considerably to this discussion (Hepp, 2013; Hjarvard, 2013; Lundby, 2009, 2014) and despite our various positions and internal disagreements in this debate, we share the view that the research field's understanding of 'mediatization' has matured, theoretically as well as empirically. Today, mediatization has been conceptually developed from various perspectives (in particular sociological and cultural). Empirical studies of mediatization processes have begun to develop in a variety of areas, including politics, religion, family and so on. As a result, we now have more elaborated and refined definitions to build upon and several empirical fields that allow us to reconsider the particular interplay between media, communications, culture and society in different sectors of culture and society. However, we are still in the early stages of this theoretical endeavor and empirical work firmly rooted in the mediatization concept is still relatively scarce.

Like most concepts, mediatization has been contested and challenged from a variety of perspectives, and a recent article in this journal by Deacon and Stanyer sets out to consider whether mediatization is a 'key concept or conceptual bandwagon' (2014: 1032). In general, we agree with Deacon and Stanyer that the term 'mediatization' is by some invoked in a casual manner with limited theoretical underpinnings and few consequences for the empirical work in question. In some contexts it may look more like a catchphrase than a real concept, perhaps demonstrating an attempt by some researchers to connect to the emerging paradigm of mediatization research without really engaging with the theoretical framework.

Having said this, we also think that Deacon and Stanyer (2014) paint too bleak a picture of the present state of mediatization research, which is partly due to the empirical methodology on which their critique rests. Their overview of current mediatization research is based on a simple word search in a sample of 14 leading media and communication journals from 2002 to 2012. Searching for the word 'mediatization,' they found 93 articles mentioning the word at least once and, not very surprisingly, they find that 'in the vast majority of cases (81 percent) the word was just mentioned in passing, more casually invoked than defined' (Deacon and Stanyer, 2014: 1034). We are confident that looking for research into, for instance, 'globalization' or 'commercialization' through a simple word search would produce a similar result. However, we do not think this necessarily implies that we must abandon the concepts of 'globalization' or 'commercialization'. We are also convinced that some 
of the researchers whose articles are included in Deacon and Stanyer's sample will be surprised to learn that their research has become exemplary of current mediatization research. Our objection to Deacon and Stanyer's methodology is not meant as an excuse for a sloppy use of the concept of mediatization in a number of articles; we emphasize the need to be precise and elaborate in the use of the term. Our objection concerns the fact that they criticize mediatization research at its weakest, whereas it should be criticized where its arguments appear strongest. Deacon and Stanyer's (2014) criticism addresses three theoretical concerns which we will consider in turn: the role of media as causal agents, the understanding of historical change and the design of concepts. At the end of the article we will conclude that the emergence of the concept of 'mediatization' is part of a paradigmatic shift within media and communication research.

\section{Media and causality}

A central objection to the mediatization argument is that it allegedly overemphasizes the role of the media as agents of change. Non-media factors are not taken sufficiently into account, creating a risk of 'automatically centre-staging media actors, logics and technologies' (Deacon and Stanyer, 2014: 1033). The 'current focus on ICTs and the media is overly media-centric with all the problems this entails', Deacon and Stanyer (2014: 1034) write. This is an important argument and - if true - clearly detrimental to a complex and nuanced understanding of the role of media in social and cultural change. We do, however, think this is a clear misunderstanding. Following Livingstone (2010), we find it important to distinguish between being 'mediacentric' and 'media-centered'. Being 'media-centric' is a one-sided approach to understanding the interplay between media, communications, culture and society, whereas being 'media-centered' involves a holistic understanding of the various intersecting social forces at work at the same time as we allow ourselves to have a particular perspective and emphasis on the role of the media in these processes.

The ambition of mediatization studies is to engage in cross-disciplinary work with, for instance, political scientists or educational researchers, but in order to make such an effort worthwhile for all involved, media and communication researchers must also be able to bring something to the table. In our experience the framework of mediatization research has already proved its ability to bridge various disciplines in fruitful ways. During a period in which other parts of our media and communication discipline are becoming ever more specialized, introverted and focused on (new) media technologies and their particular applications, mediatization studies has rearticulated a series of fundamental questions concerning the interrelationships 
between media, communications, culture and society (Hjarvard, 2012a). Mediatization is, therefore, not a media-centric postulate about the media's direct 'causal influence' on every aspect of society, but an attempt to build a theoretical framework that will allow us to discuss the influences of media and communications in other social and cultural domains with researchers from other disciplines. We attempt to be 'media-centered' (or more specifically 'media- and communication-centered') in order to engage constructively with researchers who come to the table with 'politics-centered' or 'education-centered' concepts and frameworks. There is a strong need for such a move, given the increasing relevance of media to various fields of society (Livingstone, 2009). If it is correct that media have become more important to different fields of (late) modern society such as politics, education, religion and science, scholars of media and communication research would do well to collaborate with experienced experts in these fields: scholars of political science, pedagogy, religious studies, sociology of knowledge, etc. What we can bring to such an interdisciplinary dialogue is our experience as experts in researching processes of mediated communication ('mediation') and their transforming potential ('mediatization').

Furthermore, mediatization theory does place emphasis on the role of the media, for instance by examining how media mould social interaction and shape 'communicative figurations' (Hepp, 2013; Hepp and Hasebrink, 2014) or how the logics of the media come to influence the logics of other institutions like religion or politics (Hjarvard, 2013). We find it perfectly valid to theorize about these matters; in fact we would find it strange if our field of research were not involved in doing exactly this. One can distinguish between an institutional, social-constructivist or cultural and a material perspective on mediatization (Lundby, 2014: 10-11). Regardless of the approach to mediatization the idea is not that the media 'colonize' other social or cultural domains. An institutional take sees mediatization as a social process that 'is spurred by both the development of the media and the dynamics of a variety of other institutions in which social agents try to make use of the media's resources for their own purposes' (Hjarvard, 2014b: 223). A social-constructivist or cultural approach aims 'to investigate the interrelation between the change of media communication and sociocultural change as part of everyday communication practices, and how the change of these practices is related to a changing communicative construction of reality' (Hepp, 2013: 618). The material perspective focuses on the technologies and their material properties because 'there is also a material aspect to the notions of space that are inherent in mediatization as well as in the media 'textures' through which cultural practices and everyday life materialize' (Lundby, 2014: 11). The materiality does not determine or 'colonize' other domains but both shapes and is shaped by social and cultural processes. 
That said, we agree with Deacon and Stanyer (2014) when they point to the necessity of considering a wide set of possible interactions between the factors involved at the contextually relevant macro-, meso-, and microlevels. Mediatization is not a one-way street and nor are the outcomes similar across different domains. Furthermore, media developments may not necessarily or predominantly be spurred by internal media developments but may result from a complex mix of economic, legal, technological, political and cultural factors that come to influence the structure and agency of, for instance, social network media. Thus the social influences of a social network medium like Facebook not only include the increasingly mediated character of interpersonal and group relationships but also the commodification of social relationships due to the commercial dynamics embedded in Facebook. In this way, processes of mediatization may also relay dynamics from other social and cultural domains.

Deacon and Stanyer (2014) suggest looking for the possibility of non-change in the wake of media developments, since social dynamics that resist change may be just as important to understand as social dynamics that induce transformations. This is clearly a valid argument and Fischer's (1992) study of the cultural influences of the telephone in USA may serve as a good example of such a 'conservative' influence of the media. As Fischer demonstrates, the telephone was initially not only a technology of modernization, but also a way for many people to maintain existing family ties in a world that in many other ways seemed subject to profound change. While acknowledging this, we would also like to emphasize that even a process of preserving strong social ties with the help of the media cannot just be understood as an example of non-mediatization. The telephone's ability to maintain strong social ties against the backdrop of modern America may precisely and paradoxically - account for its popularity and subsequent rise to becoming an icon of modernity and a symbol of new modern lifestyles on a par with the automobile and radio.

Finally, mediatization is not a zero-sum game in which either the media or e.g. politics come to dominate the other. Media and politics may in some respects work in tandem, enabling a simultaneous mediatization of politics and a politicization of media. The symbiotic relationship between the media's political commentators and the political parties' spin doctors is a sign of such intertwined developments. If we look at the research that explicitly addresses mediatization theory, without just taking articles that use the concept in passing as our reference point, we find a growing awareness of multidimensional factors at work. For instance, in a newly published volume on the mediatization of politics, Esser and Strömbäck (2014) try to add nuances to the original model of four phases of mediatization of politics (Strömbäck, 2008) and incorporate insights from existing media studies concepts (framing, agenda-setting, etc.) into the framework of mediatization. We are 
confident that the growing body of literature on mediatization will reflect similar nuances and complexity as regards the reciprocal influences between media and other social domains.

\section{Historical transformations}

In their criticism of causal processes, Deacon and Stanyer (2014) miss the broader perspective of mediatization research. We tried to formulate this briefly in a previous article: 'In general, the concept of mediatization tries to capture long-term interrelation processes between media change on the one hand and social and cultural change on the other' (Hepp et al., 2010: 223). This is reiterated in recent definitions of mediatization (Couldry and Hepp, 2013: 197; Lundby, 2014: 19). Hepp and Krotz (2014: 3, 5) add that this understanding of mediatization implies that we have to consider 'media' as always related to communication practices.

The weaknesses of Deacon and Stanyar's first argument have consequences for their second point of criticism, which concerns the comparisons 'over time and space' in mediatization research. Their argument here actually focuses on historical transformations. We acknowledge the understanding of mediatization as long-term processes. We agree that the concept thus implies historical change, as Deacon and Stanyar (2014) underline. As long-term structural processes, these changes can usually be identified as transformations (Schulz, 2004: 98; Hjarvard, 2014b: 125; Lundby, 2014: 7). British researchers (Couldry, 2008; Livingstone, 2009) following Silverstone $(2002,2005)$ initially regarded 'mediation' as the proper concept for capturing how processes of communication transform the social and cultural environment. However, Livingstone (with Lunt, 2014) as well as Couldry (2012: 134) have changed their mind and adopted 'mediatization' as the term for conveying historical transformations. Mediation stands as the more general term, denoting regular communication processes that do not alter the large-scale relationship between media, culture and society (Hjarvard, 2014a: 125). The two terms mediation and mediatization are not mutually exclusive, but rather complementary (Hepp, 2013: 31-38).

In a concluding comment on the contributions in the recent handbook on Mediatization of Communication (Lundby 2014), Sonia Livingstone and Peter Lunt suggest that 'mediatization research might usefully reinterpret the many existing findings of mediation research by re-locating and integrating them within a historical frame' (Livingstone and Lunt, 2014: 719). This suggestion is based on their reading of Johan Fornäs's chapter in the handbook, in which he discusses European popular culture in terms of its graphic, print, 
audiovisual and digital phases. Each period is characterized by its own transformations. However, the mediatization of each phase is rooted in different patterns of mediation (Fornäs, 2014). Livingstone and Lunt observe how Fornäs reveals 'the distinct but complementary relations between mediation and mediatization' (2014: 718), leading to their suggestion to reinterpret earlier findings within a historic frame related to mediatization processes.

Thus, we agree with Deacon and Stanyar (2014) that there is a need in mediatization research to historicize the processes, to conduct explicit historical analyses and go beyond general statements. This is a challenge to study concrete historic transformations and cases in order to make qualified conclusions about the 'before' and 'after' inherent in the mediatization thesis.

There is seemingly a huge unresolved gap in mediatization research between those who hold that mediatization is a phenomenon of the last three or four decades of more or less 'media-saturated societies' (in the western part of the world) and those who see mediatization potential in the use of media tools in communication since the very beginning of humanity (Lundby, 2014: 23-24). Hjarvard (2013: 18) is a proponent of the former, Krotz $(2009,2014)$ of the latter historical perspective. However, Krotz's current research also focuses on recent media-rich late-modern settings. That said, the distinction between these two historical perspectives is also about where one observes the changes and transformations. Hjarvard looks at the transforming patterns between various institutions in society, the media themselves becoming a semiindependent institution (Hjarvard, 2014a, 2014b). Krotz is concerned with the inner workings of the communication processes of all types of media. Thus he focuses on the transformative potential of media tools in terms of 'how people construct the social and cultural world,' which amounts to 'a specific realization' in each historical phase of a culture and society (Krotz, 2009: 24-25). In this sense the two historical perspectives refer back to the distinction between an institutionalist and social-constructivist or a cultural tradition of mediatization research. But again, it is legitimate for Deacon and Stanyar (2014) to ask for more specific historical accounts.

At this point it is important to emphasize that there are already many researchers within mediatization research who work historically (Wilke, 2011; Arnold et al., 2010; Marszolek and Robel, 2014), a point which is not discussed in detail by Deacon and Stanyer. It seems to us that a whole field of 'mediatization history' is emerging. The problem of such historical studies is their context sensitivity, which makes them less likely to be 
translated into English, and therefore they will not be represented in a keyword-based word search like the one conducted by Deacon and Stanyer. Contrary to what Deacon and Stanyer seem to expect, many of the arguments of mediatization research are grounded in solid media-historical research. This also includes historical studies of the use of the concept of 'mediatization' by sociological classics (Averbeck-Lietz 2014). But a lot of work remains to be done.

\section{Conceptual design}

When discussing the conceptual design of mediatization research, we must clarify one fundamental misunderstanding on the part of Deacon and Stanyer (2014) that relates back both to the points of 'causality' and 'historical transformations.' In essence, their implicit argument is that mediatization research concerns one-sided, causal effects - which is not the case. There is a recognizable difference between 'effect research' and 'mediatization research' (Kepplinger, 2008; Couldry and Hepp, 2013). Mediatization research is not about media effects but, as noted above, about the interrelation between the change of media and communication on the one hand and the change of (fields of) culture and society on the other hand. Media are not necessarily the 'driving forces' of transformations. There are other processes of change that might find their expression in media and communications. One example is 'individualization' (Beck and Gernsheim, 2001), which explains e.g. the differentiation of media outlets in Europe since the 1950s (which goes hand in hand with the 'concentration' of media organizations and ownerships, which we might explain by certain economic 'driving forces'). And when media are the 'driving forces' of transformations they are confronted with the 'inertia' of certain fields, interaction orders and institutional contexts. This is another focus of mediatization research. In a nutshell, mediatization research is not about 'linear effects' but about analyzing 'interrelating influences' in the original sense of Simmel (1972).

Following on from this, Deacon and Stayer simplify the conceptual levels of mediatization research. If mediatization is understood as a 'meta process' (Krotz, 2009), this does not at all mean that mediatization is 'inexorable' or 'ineffable' (Deacon and Stanyer, 2014: 1038). On the contrary, the point is that 'meta processes' (as for example also 'globalization', 'individualization' and 'commercialization') are 'theoretical constructs resting in part upon empirical evidence, but which are not empirically verifiable in their entirety' (Hepp, 2013: 49). In this sense, the concept of mediatization is already 'empirical universal,' to use the wording by Deacon and Stanyer (2014: 1041), referring back to Sartori (1970). In our view, mediatization research needs to apply a 
context-sensitive approach at the same time as concepts are operationalized within the more general analytical frame of mediatization. In this sense, the argument that mediatization would be 'a concept of no difference' is unfounded.

We also find Deacon and Stanyer's strong emphasis on 'diachronous' mediatization research problematic. As we have already emphasized, we do consider this kind of historical empirical research as fundamental. However, there are also several good arguments for supplementing the 'diachronous' approach with a 'synchronous' mediatization research.

The first argument concerns the fact that for many research questions we cannot get solid 'diachronous' data, especially when it comes to everyday practices. In this area of research, historical data for 'looking back' are rare and for 'looking ahead' we only have limited repertoires, e.g. initiating long-term panel studies. The framework of 'synchronous' research offers us additional opportunities for indirect access to transformations, for example by comparing 'media generations' (Bolin and Skogerb $\varnothing, 2013$ ) and their media practices at a given moment in time, or by conducting biographical interviews on the perceptions of media transformations and the changes of the interviewee's media practices. Methods like these offer indirect access to e.g. the mediatization of everyday practices of community building, and also in this case demonstrate the variability of the 'mediatization wave' of digitalization and the 'inertia' of fundamental community orientations (Hepp et al., 2014).

A second argument for 'synchronous' mediatization research may be traced back to the 'event as transformations' approach formulated by Sewell (2005). There are 'events' or 'situations' of intense transformations which are worth integrating into mediatization research. This is especially the case as regards 'mediatization waves,' that is, moments of qualitatively intense media change, for example when a certain digital media technology is appropriated in a certain context for the first time. In 'situations' like these in particular, we can describe the 'inertia' of a certain context, the various 'consequences' of mediatization and moments of 'de-mediatization' (Grenz and Möll, 2014; Möll and Hitzler, 2014).

Across 'diachronous' and 'synchronous' mediatization research, the conceptual design of recent studies is structured in such a way that they can describe 'driving forces' of transformation that are related to media and communications, including the 'inertia' of certain fields and institutional contexts against this and other 'driving forces' of importance. A few recent examples: Landerer (2013) as well as Esser and Strömbäck (2014) have developed empirical frameworks to investigate the mediatization of politics (primarily through traditional mass 
media) in a way that also reflects the stability of the field of politics and other influencing forces. Hepp and Hasebrink (2014) have developed the framework of 'communicative figurations' to investigate 'variation' which refers to situations when media become part of a certain social entity but do not necessarily transform anything. Hjarvard (2012b) has suggested a theoretical distinction between various aspects of media, following Meyrowitz (1993), to distinguish between various dimensions of mediatized religion. And within media sociology we can find a reformulation of 'social constructivism' as 'communicative constructivism' in the frame of mediatization research (Knoblauch, 2013). Despite their different theoretical approaches, contributions like these demonstrate a high level of awareness concerning conceptual designs and their operationalization in current mediatization research.

\section{Conclusion}

In their article, David Deacon and James Stanyer ask if mediatization is 'a key concept or a conceptual bandwagon' and they conclude that there is a risk that the concept may confuse more than it explains. As our clarification demonstrates, a conclusion like this falls short. On a final note we would like to emphasize that, in our view, 'mediatization' as a concept is part of a broader paradigm shift within media and communication research (Livingstone, 2009): In late modern societies media have become co-constitutive for the articulation of various social fields in their present form: politics, economics, education, etc. Therefore, the question of media and communication research cannot only be restricted to the study of 'mediations', e.g. the 'influence' of 'media coverage' on this or that. Instead, by focusing on 'mediatization', we must ask much more fundamentally: how are media and communications related with certain sociocultural forms and their transformation(s)? Which interrelations do we find? What consequences can we observe during these transformational processes? Such fundamental questions, which attracted us to the field of media and communication research in the first place, have in our opinion been somewhat neglected in the ongoing specialization of the research field. The framework of mediatization research is one way of putting these issues

back on the agenda. As with the early academic discussions about 'individualization' and 'globalization,' we do not yet have the final answers. However, our hope is that the - institutionalization of mediatization research represents the beginning of a similar nuanced discussion as we also try to connect the notion of 'mediatization' with the processes of 'globalization' and 'individualization'. Hopefully, we are experiencing the beginning of a fruitful discussion - in which, of course, critique is an essential component. 
Parts of the article written by Andreas Hepp are based on research conducted within the CU,Communicative Figurations' (University of Bremen, University of Hamburg), supported by the institutional strategy ,Ambitious and Agile' of the University of Bremen funded within the frame of the Excellence Initiative by the German Federal and State Governments.

\section{References}

Arnold K; Classen C; Kinnebrock S; Lersch E and Wagner HU (eds) (2010) Von der Politisierung der Medien zur Medialisierung des Politischen? Leipzig: Leipziger Universitätsverlag.

Averbeck-Lietz S (2014) Understanding mediatization in 'First Modernity': Sociological classics and their perspectives on mediated and mediatized societies. In: Lundby K (ed) Mediatization of communication. Handbooks of communication science vol. 21. Berlin: De Gruyter Mouton, pp. 109-130.

Beck U and Beck-Gernsheim E (2001) Individualization: institutionalized individualism and its social and political consequences. London, New Delhi: Sage.

Bolin G and Skogerbø E (2013) Age, generation and the media. Northern Lights: Film \& Media Studies Yearbook 11(1): 3-14.

Couldry N (2008) Mediatization or mediation? Alternative understandings of the emergent space of digital storytelling. New Media \& Society 10(3): 373-391.

Couldry N (2012) Media, Society, World. Social Theory and Digital Media Practice. Cambridge: Polity.

Couldry N and Hepp A (2013) Conceptualizing Mediatization: Contexts, Traditions, Arguments. Communication Theory 23(3): 191-202.

Deacon D and Stanyer J (2014) Mediatization: Key Concept or Conceptual Bandwagon? Media, Culture \& Society. 36(7): 1032-1044.

Esser F and Strömbäck J (eds) (2014) Mediatization of Politics. Understanding the Transformation of Western Democracies. New York: Palgrave Macmillan. 
Fischer CS (1992) America Calling: A Social History of the Telephone to 1940. Berkeley: University of California Press.

Fornäs J (2014) Mediatization of popular culture. In Lundby K (ed) Mediatization of Communication. Handbooks of Communication Science vol. 21. Berlin: De Gruyter Mouton, pp. 483-504.

Grenz, T. and G. Möll (2014) Zur Einleitung: Mediatisierung von Handlungsfeldern. In: Grenz T, and Möll G (eds.) Unter Mediatisierungsdruck. Wiesbaden: VS, pp. 1-15.

Hepp A (2013) Cultures of Mediatization. Cambridge: Polity.

Hepp A, Hjarvard S and Lundby K (2010) Mediatization - Empirical perspectives: An introduction to a special issue. Communications. The European Journal of Communication Research 35(3): 223-228.

Hepp A and Krotz F (eds) (2014) Mediatized Worlds. Culture and Society in a Media Age. Basingtoke: Palgrave Macmillan.

Hepp A, Berg M and Roitsch C (2014) Mediatized worlds of communitization: Young people as localists, centrists, multi-localists and pluralists. In: Hepp A and Krotz F (eds.) Mediatized worlds: Culture and society in a media age. Basingtoke: Palgrave Macmillan, pp. 174-203.

Hepp, A and Hasebrink U (2014) Human interaction and communicative figurations: The transformation of mediatized cultures and societies. In: Lundby K (ed) Mediatization of Communication. Handbooks of Communication Science vol. 21. Berlin: De Gruyter Mouton, pp. 249-272.

Hjarvard S (2012a) Doing the Right Thing: Media and Communication Studies in a Mediatized World. Nordicom Review 33 (Supplement 1): 27-34.

Hjarvard S (2012b) Three forms of mediatized religion. Changing the public face of religion. In: Hjarvard S and Lövheim, M Mediatization and religion. Gothenburg: Nordicom, pp. 21-44.

Hjarvard S (2013) The Mediatization of Culture and Society. London: Routledge.

Hjarvard S (2014a) From Mediation to Mediatization: The Institutionalization of New Media. In: Hepp A and Krotz F (eds) Mediatized Worlds. Culture and Society in a Media Age. Basingtoke: Palgrave Macmillan, pp. 123139. 
Hjarvard S (2014b) Mediatization and cultural and social change: an institutional perspective. In: K. Lundby (ed) Mediatization of Communication. Handbooks of Communication Science vol. 21. Berlin: De Gruyter Mouton, pp. 199-226.

Kepplinger HM (2008) Was unterscheidet die Mediatisierungsforschung von der Medienwirkungsforschung? Publizistik 53(3): 326-338.

Knoblauch H (2013) Communicative constructivism and mediatization. Communication Theory 23 (3): 297-315. Krotz F (2009) Mediatization: A Concept With Which to Grasp Media and Societal Change. In: Lundby K (ed) Mediatization: Concept, Changes, Consequences. New York: Peter Lang, pp. 21-40.

Krotz F (2014) Mediatization as a mover in modernity: social and cultural change in the context of media change. In: Lundby, K (ed) Mediatization of Communication. Handbooks of Communication Science vol. 21. Berlin: De Gruyter Mouton, pp. 131-161.

Landerer N (2013) Rethinking the logics: A conceptual framework for the mediatization of politics. Communication Theory 23(3): 239-258.

Livingstone S (2009) On the Mediation of Everything. Journal of Communication 59(1): 1-18.

Livingstone S (2010) Youthful Participation: What have we learned, what shall we ask next? Keynote at First Annual Digital Media and Learning Conference: Diversifying Participation. Available online: http://dmlcentral.net/sites/dmlcentral/files/resource_files/Digital_Media_and_Learning_conference_keynote _Livingstone_final.pdf (accessed 19 August 2014)

Livingstone S and Lunt P (2014) Mediatization: an emerging paradigm for media and communication research. In Lundby K (ed) Mediatization of Communication. Handbooks of Communication Science vol. 21. Berlin: De Gruyter Mouton, pp. 703-723.

Lundby K (ed) (2014) Mediatization of Communication. Handbooks of Communication Science vol. 21. Berlin: De Gruyter Mouton.

Lundby K (ed) (2009) Mediatization: Concept, Changes, Consequences. New York: Peter Lang. 
Marszolek I and Y Robel (2014) Mediengeschichte als Geschichte kommunikativer Figurationen..

Communicative figurations working paper 4. Available online: http://www.kommunikative-

figurationen.de/fileadmin/redak_kofi/Arbeitspapiere/CoFi_EWP_No-4_Marszolek-Robel.pdf (accessed 10

October 2014)

Meyrowitz J (1993) Images of the media: Hidden ferment - and harmony - in the field. Journal of communication 43(3): 55-66.

Möll G and Hitzler R (2014) Falsches Spiel mit dem Sport. Zur Mediatisierung von Sportwetten und ihren nichtintendierten Nebenfolgen. In: Grenz T and Möll G (eds) Unter Mediatisierungsdruck. Wiesbaden: VS, pp. 169-187.

Schulz W (2004) Reconstructing mediatization as an analytical concept. European Journal of Communication 19(1): 87-101.

Silverstone R (2002) Complicity and collision in the mediation of everyday life. New Literary History 33(4): 745764.

Silverstone R (2005) Media and communication. In: Calhoun C, Rojek C and Turner B (eds) The International Handbook of Sociology. London: Sage, pp. 188-208.

Sartori G (1970) Concept misformation in comparative politics. The American political science review 64(4): 1033-1053.

Sewell W H (2005) Logics of history: Social theory and social transformation. Chicago: University of Chicago Press.

Simmel G (1972) On individuality and social forms, edited by and with an introduction by Donald Levine. Chicago: University of Chicago Press.

Strömbäck J (2008) Four Phases of Mediatization: An Analysis of the Mediatization of Politics. The International Journal of Press/Politics 13(3): 228-246.

Wilke J (2011) Von der frühen Zeitung zur Medialisierung. Bremen: edition lumière. 